\title{
Up-Regulation of Excitatory Amino Acid Transporters EAAT3 and EAAT4 by Lithium Sensitive Glycogen Synthase Kinase GSK3ß
}

\author{
Abeer Abousaaba Florian Lang ${ }^{a, b}$ \\ aDepartment of Cardiology, Vascular Medicine and Physiology I, University of Tuebingen, Tuebingen, \\ 'Department of Molecular Medicine II, Heinrich Heine University Duesseldorf, Duesseldorf, Germany
}

Key Words

Neuroexcitability $\bullet$ Lithium $•$ Glutamate transporter $・$ SLC1A1 $・$ SLC1A6

\begin{abstract}
Background: Cellular uptake of glutamate by the excitatory amino-acid transporters (EAATs) decreases excitation and thus participates in the regulation of neuroexcitability. Kinases impacting on neuronal function include Lithium-sensitive glycogen synthase kinase GSK3B. The present study thus explored whether the activities of EAAT3 and/or EAAT4 isoforms are sensitive to GSK3B. Methods: cRNA encoding wild type EAAT3 (SLC1A1) or EAAT4 (SLC1A6) was injected into Xenopus oocytes without or with additional injection of CRNA encoding wild type GSK3ß or the inactive mutant ${ }^{\mathrm{K} 8 \mathrm{AA}} \mathrm{GSK} 3 ß$. Dual electrode voltage clamp was performed in order to determine glutamate-induced current $\left(\mathrm{I}_{\text {EAAT }}\right)$. Results: Appreciable $\mathrm{I}_{\text {EAAT }}$ was observed in EAAT3 or EAAT4 expressing but not in water injected oocytes. $\mathrm{I}_{\text {EAAT }}$ was significantly increased by coexpression of GSK3B but not by coexpression of ${ }^{\mathrm{K} 85 \mathrm{~A} G S K 3 B}$. Coexpression of GSK3B increased significantly the maximal $\mathrm{I}_{\text {EAAT }}$ in EAAT3 or EAAT4 expressing oocytes, without significantly modifying apparent affinity of the carriers. Lithium $(1 \mathrm{mM})$ exposure for 24 hours decreased $\mathrm{I}_{\text {EAAT }}$ in EAAT3 and GSK3B expressing oocytes to values similar to $\mathrm{I}_{\text {EAAT }}$ in oocytes expressing EAAT3 alone. Lithium did not significantly modify $\mathrm{I}_{\text {EAAT }}$ in oocytes expressing EAAT3 without GSK3B. Conclusions: Lithiumsensitive GSK3ß is a powerful regulator of excitatory amino acid transporters EAAT3 and EAAT4.

(C) 2016 The Author(s)

Published by S. Karger AG, Basel
\end{abstract}

\section{Introduction}

Glutamate transporters clear glutamate from synaptic clefts and thus counteract excitotoxicity [1-5]. The EAAT3 isoform is expressed in neurons [6-13], retinal ganglion cells [14], and glial cells [12, 15-17]. EAAT4 is expressed in cerebellar Purkinje cells and clears glutamate from the synapses connecting the climbing fibers with the Purkinje cells $[10,18]$. 
Dysregulation of EAAT3 has been implicated in schizophrenia [19-25], epilepsy [2630] and hepatic encephalopathy [31], dysregulation of EAAT4 has been associated with schizophrenia [19, 20].

Regulators of neuronal excitability include the glycogen synthase kinase GSK3ß [32], a serine/threonine kinase inhibited by the antidepressant Lithium [33]. GSK3ß is phosphorylated and down-regulated by protein kinase B (PKB/Akt) [34].

The present study explored whether GSK3ß influences the activity of the glutamate transporters EAAT3 (SLC1A1) or EAAT4 (SLC1A6). To this end, the carriers were expressed in Xenopus oocytes without and with additional expression of wild type GSK3ß or inactive ${ }^{\mathrm{K} 85 \mathrm{~A}} \mathrm{GSK} 3 ß$ and electrogenic glutamate transport quantified by dual electrode voltage clamp.

\section{Materials and Methods}

\section{Constructs}

For generation of cRNA [35, 36], constructs were used encoding wild-type human EAAT3 [37], EAAT4 [37], wild type GSK3ß and inactive mutant ${ }^{\mathrm{K} 85 \mathrm{~A}} \mathrm{GSK} 3 ß$ [38]. The constructs were generated by site-directed mutagenesis (QuikChange II XL Site-Directed Mutagenesis Kit; Stratagene, Heidelberg, Germany) according to the manufacturer's instructions [39]. The mutants were sequenced to verify the presence of the desired mutation and used for generation of cRNA as described previously [40-42].

Voltage clamp in Xenopus oocytes

Xenopus oocytes were prepared as previously described [43-45]. 10 ng of wild type GSK3ß or ${ }^{\mathrm{K} 85 \mathrm{~A} G S K 3 ß}$ cRNA were injected on the first day and 10 ng EAAT3 or EAAT4 cRNA on the same day after preparation of the oocytes. The oocytes were maintained at $17^{\circ} \mathrm{C}$ in ND96-A solution containing (in $\mathrm{mM}$ ): $88.5 \mathrm{NaCl}, 2 \mathrm{KCl}, 1$ $\mathrm{MgC1}_{2}, 1.8 \mathrm{CaC}_{2}, 2.5 \mathrm{NaOH}, 5 \mathrm{HEPES}, 5$ sodium pyruvate $\left(\mathrm{C}_{3} \mathrm{H}_{3} \mathrm{NaO}_{3}\right)$, Gentamycin $(100 \mathrm{mg} / \mathrm{l})$, Tetracycline (50 mg/l), Ciprofloxacin (1.6 mg/l), Theophiline $(90 \mathrm{mg} / \mathrm{l})$. The $\mathrm{pH}$ was titrated to $7.4 \mathrm{using} \mathrm{NaOH}$. Where indicated, Lithium (1 $\mathrm{mM}$ ) was added. The voltage clamp experiments [46-48] were performed at room temperature 3 days after injection. Two-electrode voltage-clamp recordings were performed at a holding potential of $-70 \mathrm{mV}$. The data were filtered at $10 \mathrm{~Hz}$ and recorded with a Digidata A/D-D/A converter and Clampex V.9 software for data acquisition and analysis (Axon Instruments)[49-51]. The control superfusate ND96 contained (in mM) $93.5 \mathrm{NaCl}, 2 \mathrm{KCl}, 1.8 \mathrm{CaCl}_{2}, 1 \mathrm{MgCl}_{2} 2.5 \mathrm{NaOH}$ and 5 HEPES (pH 7.4). The flow rate of the superfusion was approx. $20 \mathrm{ml} / \mathrm{min}$, and a complete exchange of the bath solution was reached within about $10 \mathrm{~s}$. Glutamate was added to the solutions at the indicated concentrations. The flow rate of the superfusion was approx. $20 \mathrm{ml} / \mathrm{min}$, and a complete exchange of the bath solution was reached within about $10 \mathrm{~s}[52-54]$.

\section{Statistical analysis}

Data are provided as means \pm SEM, $n$ represents the number of oocytes investigated. All experiments were repeated with at least 3 batches of oocytes; in all repetitions qualitatively similar data were obtained. As expression of injected cRNA may vary from batch to batch of oocytes, comparisons were always made within the same oocyte batch $[55,56]$. Data were tested for significance using ANOVA or t-test, as appropriate. Results with $\mathrm{p}<0.05$ were considered statistically significant.

\section{Results}

The present study explored whether the glycogen synthase kinase GSK3ß modifies the function of the glutamate transporters EAAT3 and EAAT4. To this end, cRNA encoding EAAT3 or EAAT4 was injected into Xenopus laevis oocytes with or without additional injection of cRNA encoding GSK3ß. Glutamate-induced current determined by dual electrode voltage clamp was taken as measure of transport.

As illustrated in Fig. 1, addition of glutamate to the superfusate did not elicit an appreciable current in water-injected oocytes. Accordingly, the oocytes did not express 


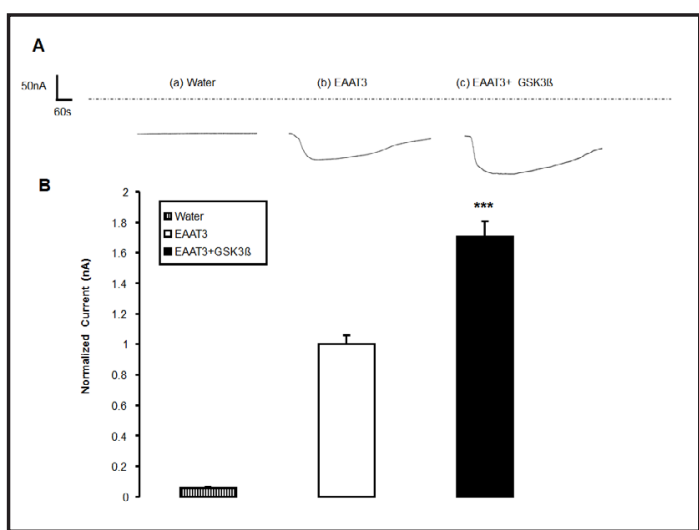

Fig. 1. Effect of wild-type GSK3ß on electrogenic glutamate transport in EAAT3 expressing Xenopus laevis oocytes. A: Representative original tracings showing glutamate $(1 \mathrm{mM})$ - induced current $\left(\mathrm{I}_{\mathrm{EAAT}}\right)$ in Xenopus laevis oocytes injected with water (a) or expressing EAAT3 without (b) or with (c) additional co-expression of wild-type GSK3ß. B: Arithmetic means \pm SEM $(n=19-23)$ of $\mathrm{I}_{\text {EAAT }}$ in Xenopus laevis oocytes injected with water (striated bar), or expressing EAAT3 without (white bar) or with wildtype GSK3ß (black bar). ${ }^{* * *}(p<0.001)$ indicates statistically significant difference from the absence of GSK3ß.

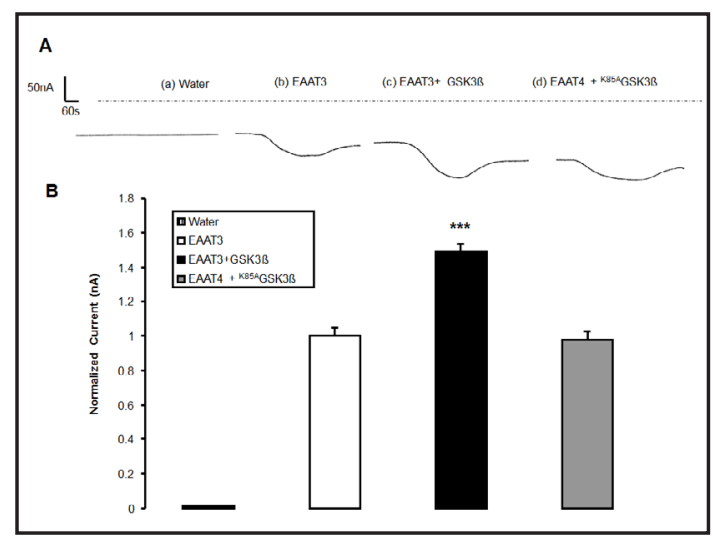

Fig. 2. Effect of inactive mutant ${ }^{\mathrm{K} 85 \mathrm{~A} G S K 3 ß}$ on electrogenic glutamate transport in EAAT3 expressing Xenopus laevis oocytes. A: Representative original tracings showing glutamate $(1 \mathrm{mM})$ - induced current $\left(\mathrm{I}_{\mathrm{EAAT}}\right)$ in Xenopus laevis oocytes injected with water (a), expressing EAAT3 alone (b) or expressing EAAT3 with additional co-expression of wild-type GSK3ß (c), or catalytically inactive ${ }^{\mathrm{K} 85 \mathrm{~A} G S K 3 ß ~(d) . ~ B: ~}$ Arithmetic means \pm SEM $(n=13-15)$ of $I_{\text {EAAT }}$ in Xenopus laevis oocytes injected with water (striated bar) or expressing EAAT3 without (white bar) or with wild-type GSK3ß (black bar), or catalytically inactive ${ }^{\mathrm{K} 85 \mathrm{~A}} \mathrm{GSK} 3 ß$ (grey bar) ${ }^{* * *}(\mathrm{p}<0.001)$ indicates statistically significant difference from oocytes expressing EAAT3 alone.

significant endogenous electrogenic glutamate transport. In EAAT3 expressing oocytes, however, the addition of glutamate to the superfusate was followed by appearance of an inward current. The additional co-expression of wild-type GSK3ß was followed by a significant increase of glutamate-induced current in EAAT3 expressing Xenopus laevis oocytes.

In contrast to wild-type GSK3ß, the inactive ${ }^{\mathrm{K} 85 \mathrm{~A}} \mathrm{GSK} 3 ß$ mutant did not significantly modify the glutamate induced-current in EAAT3 expressing Xenopus oocytes (Fig. 2).

In order to test whether GSK3ß co-expression modifies the maximal glutamate-induced current or the affinity of the carrier, the current induced by glutamate concentrations ranging from $1 \mu \mathrm{M}$ to $5 \mathrm{mM}$ was determined in Xenopus laevis oocytes expressing EAAT3 without or with additional expression of wild-type GSK3ß. As illustrated in Fig. 3, the glutamate induced-current was a function of the extracellular glutamate concentration. Kinetic analysis revealed that the maximal glutamate induced current was significantly $(p<0.001)$ lower in Xenopus laevis oocytes expressing EAAT alone (61.92 $\pm 4.17 \mathrm{nA}, \mathrm{n}=10)$ than in Xenopus laevis oocytes expressing EAAT3 together with wild-type GSK3ß $(86.03 \pm 3.41 \mathrm{nA}, \mathrm{n}=10)$. The concentration required for half-maximal glutamate induced current was not significantly different between Xenopus oocytes expressing EAAT3 alone $(652.04 \pm 61.96 \mu \mathrm{M}, \mathrm{n}=10)$ and Xenopus oocytes expressing EAAT3 together with wild-type GSK3ß $(562.36 \pm 80.88 \mu \mathrm{M}, \mathrm{n}=$ $10)$.

As GSK3ß could be inhibited by Lithium, additional experiments were performed in Xenopus oocytes expressing both EAAT3 and wild-type GSK3ß with or without prior exposure to $1 \mathrm{mM}$ Lithium. As illustrated in Fig. 4, a 24 hours treatment with Lithium significantly decreased the glutamate-induced current in Xenopus oocytes expressing both EAAT3 and wild-type GSK3ß. In Xenopus oocytes expressing EAAT3 alone, however, a 24 hours treatment with Lithium did not significantly modify the glutamate-induced current 


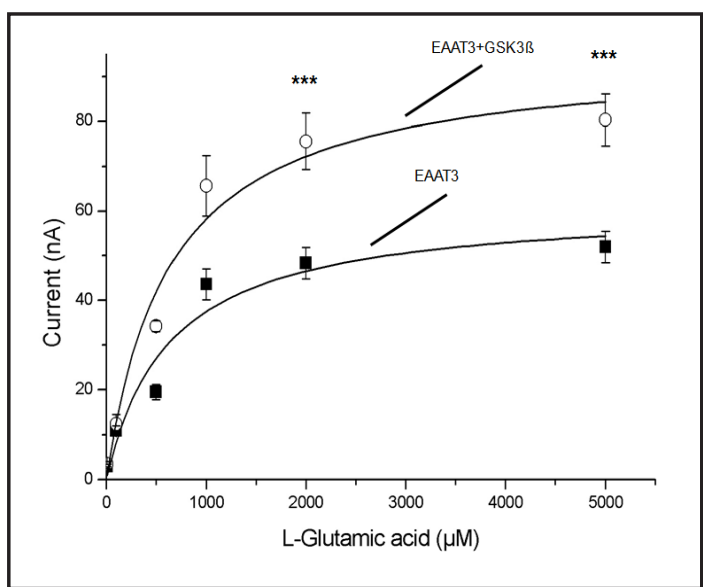

Fig. 3. Electrogenic glutamate transport in EAAT3expressing Xenopus laevis oocytes as a function of glutamate concentration without and with presence of wild-type GSK3ß. Arithmetic means \pm SEM ( $n=$ 10) of $I_{\text {EAAT }}$ as a function of glutamate concentration in Xenopus laevis oocytes expressing EAAT3 without (black squares), or with (white circles) additional co-expression of wild-type GSK3ß. *** $(\mathrm{p}<0.001)$ indicates statistically significant difference from oocytes expressing EAAT3 alone.

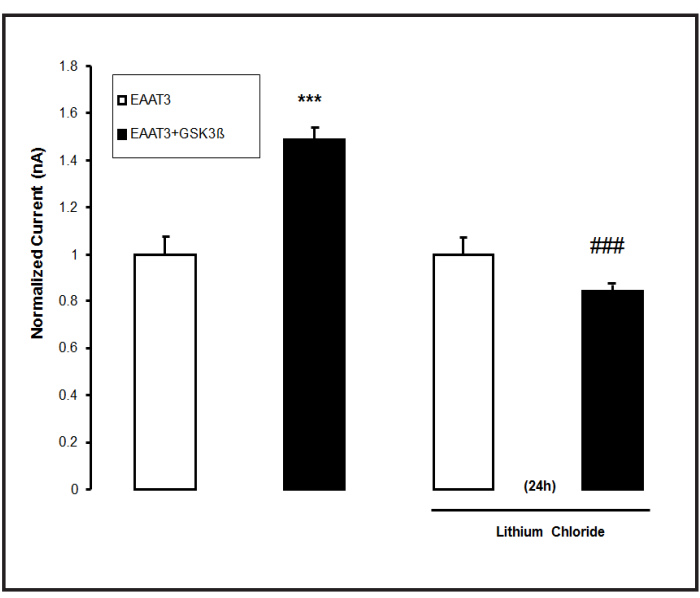

Fig. 4. Effect of Lithium on electrogenic glutamate transport in EAAT3 and GSK3ß expressing Xenopus laevis oocytes. Arithmetic means \pm SEM $(n=17)$ of $\mathrm{I}_{\text {EAAT }}$ in Xenopus oocytes expressing EAAT3 alone (white bars), or expressing EAAT3 together with wild-type GSK3ß (black bars) without (left bars) or with (right bars) prior exposure to GSK3ß inhibitor Lithium (1 mM) for 24 hours. ${ }^{* * *}(p<0.001)$ indicates statistically significant difference from Xenopus oocytes expressing EAAT3 alone, \#\#\# ( $p<0.001)$ indicates statistically significant $(p<0.001)$ difference from the absence of Lithium.
Fig. 5. Effect of wild-type GSK3ß on electrogenic glutamate transport in EAAT4 expressing Xenopus laevis oocytes. A: Representative original tracings showing glutamate $(1 \mathrm{mM})$ - induced current $\left(\mathrm{I}_{\text {EAAT }}\right)$ in Xenopus laevis oocytes injected with water (a) or expressing EAAT4 without (b) or with (c) additional co-expression of wild-type GSK3ß. B: Arithmetic means \pm SEM $(n=23)$ of $\mathrm{I}_{\text {EAAT }}$ in Xenopus laevis oocytes injected with water (striated bar), or expressing EAAT4 without (white bar) or with wild-type GSK3ß (black bar). ${ }^{* * *}(p<0.001)$ indicates statistically significant difference from the absence of GSK3ß.

(Fig. 4). Thus, Lithium abrogated the stimulating effect of GSK3ß on EAAT3, but did not influence EAAT3 activity in the absence of GSK3ß.

Similar observations were made in oocytes expressing EAAT4. As shown in Fig. 5, addition of glutamate to the superfusate did again not elicit an appreciable current in waterinjected oocytes. In EAAT4 expressing oocytes, however, the addition of glutamate to the superfusate was followed by appearance of an inward current. The additional co-expression of wild-type GSK3ß was followed by a significant increase of glutamate induced-current in EAAT4 expressing Xenopus laevis oocytes. In contrast to wild-type GSK3ß, the inactive ${ }^{\mathrm{K} 85 \mathrm{~A}} \mathrm{GSK} 3 ß$ mutant did not significantly modify the glutamate-induced current in EAAT4 expressing Xenopus oocytes (Fig. 6).

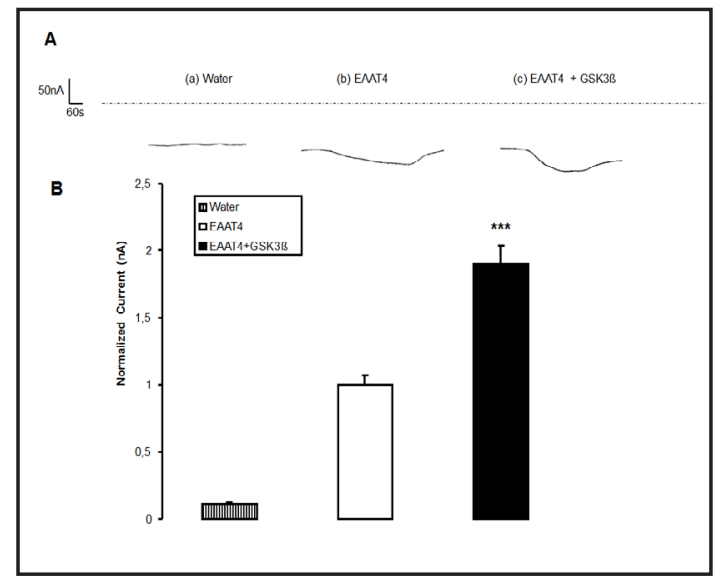




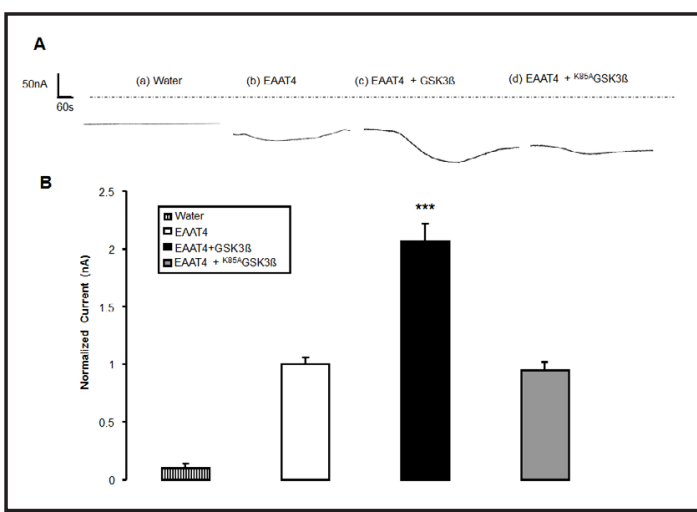

Fig. 6. Effect of inactive mutant ${ }^{\mathrm{K} 85 \mathrm{~A}} \mathrm{GSK} 3 ß$ on electrogenic glutamate transport in EAAT4 expressing Xenopus laevis oocytes. A: Representative original tracings showing glutamate $(1 \mathrm{mM})$ - induced current $\left(\mathrm{I}_{\mathrm{EAAT}}\right)$ in Xenopus laevis oocytes injected with water (a), expressing EAAT4 alone (b) or expressing EAAT4 with additional co-expression of wild-type GSK3ß (c), or catalytically inactive ${ }^{\mathrm{K} 85 \mathrm{~A} G S K 3 ß ~(d) . ~ B: ~}$ Arithmetic means \pm SEM $(n=14-16)$ of $I_{\text {EAAT }}$ in Xenopus laevis oocytes injected with water (striated bar) or expressing EAAT4 without (white bar) or with wild-type GSK3ß (black bar), or catalytically inactive

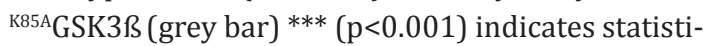
cally significant difference from oocytes expressing EAAT4 alone.

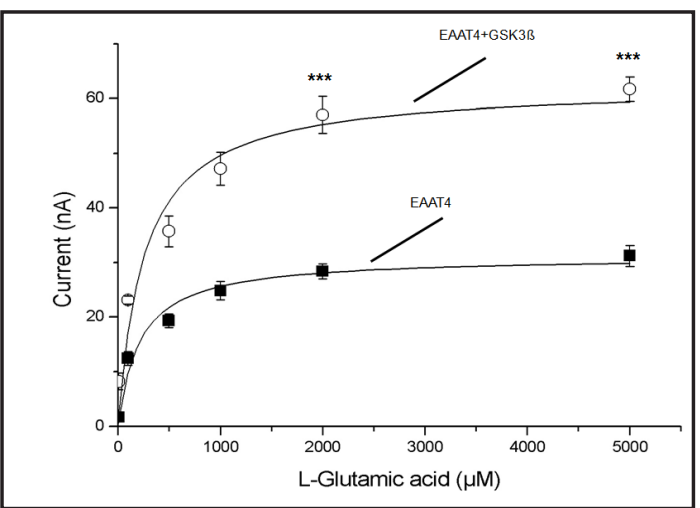

Fig. 7. Electrogenic glutamate transport in EAAT4expressing Xenopus laevis oocytes as a function of glutamate concentration without and with presence of wild-type GSK3ß. Arithmetic means \pm SEM ( $n=$ 8) of $I_{\text {EAAT }}$ as a function of glutamate concentration in Xenopus laevis oocytes expressing EAAT4 without (black squares), or with (white circles) additional co-expression of wild-type GSK3ß.*** $(\mathrm{p}<0.001)$ indicates statistically significant difference from oocytes expressing EAAT4 alone.

Again, the current induced by glutamate concentrations ranging from $1 \mu \mathrm{M}$ to $5 \mathrm{mM}$ was determined in Xenopus laevis oocytes expressing EAAT4 without or with additional expression of wild-type GSK3ß. As illustrated in Fig. 7, the glutamate-induced current was a function of the extracellular glutamate concentration. Kinetic analysis revealed that the maximal glutamate-induced current was significantly $(p<0.001)$ lower in Xenopus laevis oocytes expressing EAAT4 alone $(31.11 \pm 1.85 \mathrm{nA}, \mathrm{n}=8)$ than in Xenopus laevis oocytes expressing EAAT4 together with wild-type GSK3ß $(63.64 \pm 2.80 \mathrm{nA}, \mathrm{n}=7)$. The concentration required for half-maximal glutamate-induced current was not significantly different between Xenopus oocytes expressing EAAT4 alone $(217.21 \pm 26.08 \mu \mathrm{M}, \mathrm{n}=8)$ and Xenopus oocytes expressing EAAT4 together with wild-type GSK3ß $(298.39 \pm 41.26 \mu \mathrm{M}, \mathrm{n}=7)$.

\section{Discussion}

The present observations revealed that GSK3ß is a powerful regulator of the excitatory amino acid transporters EAAT3 and EAAT4. GSK3ß increased electrogenic glutamate transport in EAAT3 and EAAT4 expressing Xenopus oocytes. In contrast, the inactive mutant ${ }^{\mathrm{K} 85 \mathrm{~A}} \mathrm{GSK} 3 ß$ failed to modify the glutamate induced current. Thus, kinase activity is apparently required for GSK3ß mediated regulation of EAAT3 and EAAT4 transport activity.

Coexpression of GSK3ß increased significantly the maximal glutamate-induced current, without significantly modifying affinity of the carriers. Possibly, GSK3ß increases the abundance of carrier protein in the plasma membrane.

At least in theory, dysregulation of excitatory amino acid transporters could contribute to the complex neuronal actions of the kinase. As were expected [33], the effect of GSK3ß on the glutamate induced current was abrogated by Lithium. Whether or not the effect on excitatory 


\section{Cellular Physiology Cell Physiol Biochem 2016;40:1252-1260 \begin{tabular}{l|l|l}
\hline DOI: 10.1159/000453179 & $\begin{array}{l}\text { C) 2016 The Author(s). Published by S. Karger AG, Basel } \\
\text { www.karger.com/cpb }\end{array}$ \\
\hline
\end{tabular} \\ Abousaab/Lang: GSK3B Up-Regulates EAAT3/4}

amino acid transporters contributes to the pleotropic actions of this widely used antidepressant drug, cannot be answered by the present experiments.

Besides its potential impact on neuronal function, GSK3ß sensitive regulation of EAAT3 may modify a variety of further functions, as EAAT3 is expressed in a variety of cells and tissues, including blood platelets [57, 58], heart [59], renal podocytes [60], epididymis [61], placenta $[62,63]$ and blood-brain barrier [64]. In view of the present observations, glutamate uptake into the respective cells is expected to be sensitive to GSK3ß activity.

In conclusion, Lithium sensitive GSK3ß is a powerful stimulator of the excitatory amino acid transporters EAAT3 and EAAT4. Regulation of the carriers may thus contribute to the impact of neuronal and extracerebral functions of this ubiquitously expressed kinase.

\section{Acknowledgements}

The authors acknowledge the meticulous preparation of the manuscript by Lejla Subasic and technical support by Elfriede Faber. Abeer Abousaab is supported by the Deutsche Akademische Austauschdienst (DAAD)

\section{Disclosure Statement}

The authors of this manuscript state that they do not have any conflict of interests and nothing to disclose.

\section{References}

1 Beart PM, O'Shea RD: Transporters for L-glutamate: an update on their molecular pharmacology and pathological involvement. Br J Pharmacol 2007;150:5-17.

2 Estrada Sanchez AM, Mejia-Toiber J, Massieu L: Excitotoxic neuronal death and the pathogenesis of Huntington's disease. Arch Med Res 2008;39:265-276.

3 Foran E, Trotti D: Glutamate transporters and the excitotoxic path to motor neuron degeneration in amyotrophic lateral sclerosis. Antioxid Redox Signal 2009;11:1587-1602.

4 Markowitz AJ, White MG, Kolson DL, Jordan-Sciutto KL: Cellular interplay between neurons and glia: toward a comprehensive mechanism for excitotoxic neuronal loss in neurodegeneration. Cell Scie 2007;4:111-146.

5 Sheldon AL, Robinson MB: The role of glutamate transporters in neurodegenerative diseases and potential opportunities for intervention. Neurochem Int 2007;51:333-355.

6 Amara SG, Fontana AC: Excitatory amino acid transporters: keeping up with glutamate. Neurochem Int 2002;41:313-318.

7 Collin M, Backberg M, Ovesjo ML, Fisone G, Edwards RH, Fujiyama F, Meister B: Plasma membrane and vesicular glutamate transporter mRNAs/proteins in hypothalamic neurons that regulate body weight. Eur J Neurosci 2003;18:1265-1278.

8 Furuta A, Martin LJ, Lin CL, Dykes-Hoberg M, Rothstein JD: Cellular and synaptic localization of the neuronal glutamate transporters excitatory amino acid transporter 3 and 4. Neurosci 1997;81:1031-1042.

9 Furuta A, Takashima S, Yokoo H, Rothstein JD, Wada K, Iwaki T: Expression of glutamate transporter subtypes during normal human corticogenesis and type II lissencephaly. Brain Res Dev Brain Res 2005;155:155-164.

10 Huang YH, Dykes-Hoberg M, Tanaka K, Rothstein JD, Bergles DE: Climbing fiber activation of EAAT4 transporters and kainate receptors in cerebellar Purkinje cells. J Neurosci 2004;24:103-111.

11 Nieoullon A, Canolle B, Masmejean F, Guillet B, Pisano P, Lortet S: The neuronal excitatory amino acid transporter EAAC1/EAAT3: does it represent a major actor at the brain excitatory synapse? J Neurochem 2006;98:1007-1018. 


\section{Cellular Physiology Cell Physiol Biochem 2016;40:1252-1260

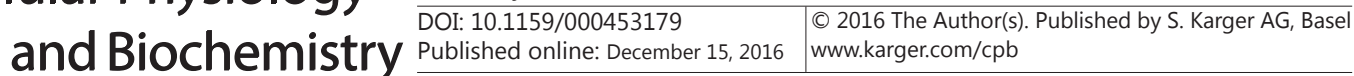 \\ Abousaab/Lang: GSK3ß Up-Regulates EAAT3/4}

12 Schmitt A, Zink M, Petroianu G, May B, Braus DF, Henn FA: Decreased gene expression of glial and neuronal glutamate transporters after chronic antipsychotic treatment in rat brain. Neurosci Lett 2003;347:81-84.

13 Shashidharan P, Huntley GW, Murray JM, Buku A, Moran T, Walsh MJ, Morrison JH, Plaitakis A: Immunohistochemical localization of the neuron-specific glutamate transporter EAAC1 (EAAT3) in rat brain and spinal cord revealed by a novel monoclonal antibody. Brain Res 1997;773:139-148.

14 Schniepp R, Kohler K, Ladewig T, Guenther E, Henke G, Palmada M, Boehmer C, Rothstein JD, Broer S, Lang F: Retinal colocalization and in vitro interaction of the glutamate transporter EAAT3 and the serum- and glucocorticoid-inducible kinase SGK1 [correction]. Invest Ophthalmol Vis Sci 2004;45:1442-1449.

15 Maragakis NJ, Dietrich J, Wong V, Xue H, Mayer-Proschel M, Rao MS, Rothstein JD: Glutamate transporter expression and function in human glial progenitors. Glia 2004;45:133-143.

16 Miralles VJ, Martinez-Lopez I, Zaragoza R, Borras E, Garcia C, Pallardo FV, Vina JR: Na+ dependent glutamate transporters (EAAT1, EAAT2, and EAAT3) in primary astrocyte cultures: effect of oxidative stress. Brain Res 2001;922:21-29.

17 van Landeghem FK, Weiss T, von Deimling A: Expression of PACAP and glutamate transporter proteins in satellite oligodendrocytes of the human CNS. Regul Pept 2007;142:52-59.

18 Furuta A, Rothstein JD, Martin LJ: Glutamate transporter protein subtypes are expressed differentially during rat CNS development. J Neurosci 1997;17:8363-8375.

19 Lang UE, Puls I, Muller DJ, Strutz-Seebohm N, Gallinat J: Molecular mechanisms of schizophrenia. Cell Physiol Biochem 2007;20:687-702.

20 Deng X, Shibata H, Takeuchi N, Rachi S, Sakai M, Ninomiya H, Iwata N, Ozaki N, Fukumaki Y: Association study of polymorphisms in the glutamate transporter genes SLC1A1, SLC1A3, and SLC1A6 with schizophrenia. Am J Med Genet B Neuropsychiatr Genet 2007;144B:271-278.

21 Huerta I, McCullumsmith RE, Haroutunian V, Gimenez-Amaya JM, Meador-Woodruff JH: Expression of excitatory amino acid transporter interacting protein transcripts in the thalamus in schizophrenia. Synapse 2006;59:394-402.

22 Kim JH, Do SH, Kim YL, Zuo Z: Effects of chronic exposure to ethanol on glutamate transporter EAAT3 expressed in Xenopus oocytes: evidence for protein kinase C involvement. Alcohol Clin Exp Res 2005;29:2046-2052.

23 McCullumsmith RE, Meador-Woodruff JH: Striatal excitatory amino acid transporter transcript expression in schizophrenia, bipolar disorder, and major depressive disorder. Neuropsychopharmacology 2002;26:368-375.

24 Nudmamud-Thanoi S, Piyabhan P, Harte MK, Cahir M, Reynolds GP: Deficits of neuronal glutamatergic markers in the caudate nucleus in schizophrenia. J Neural Transm Suppl 2007;281-285.

25 Smith RE, Haroutunian V, Davis KL, Meador-Woodruff JH: Expression of excitatory amino acid transporter transcripts in the thalamus of subjects with schizophrenia. Am J Psychiatry 2001;158:1393-1399.

26 Rakhade SN, Loeb JA: Focal reduction of neuronal glutamate transporters in human neocortical epilepsy. Epilepsia 2008;49:226-236.

27 Crino PB, Jin H, Shumate MD, Robinson MB, Coulter DA, Brooks-Kayal AR: Increased expression of the neuronal glutamate transporter (EAAT3/EAAC1) in hippocampal and neocortical epilepsy. Epilepsia 2002;43:211-218.

28 Mathern GW, Mendoza D, Lozada A, Pretorius JK, Dehnes Y, Danbolt NC, Nelson N, Leite JP, Chimelli L, Born DE, Sakamoto AC, Assirati JA, Fried I, Peacock WJ, Ojemann GA, Adelson PD: Hippocampal GABA and glutamate transporter immunoreactivity in patients with temporal lobe epilepsy. Neurology 1999;52:453472.

29 Proper EA, Hoogland G, Kappen SM, Jansen GH, Rensen MG, Schrama LH, van Veelen CW, van Rijen PC, van Nieuwenhuizen O, Gispen WH, de Graan PN: Distribution of glutamate transporters in the hippocampus of patients with pharmaco-resistant temporal lobe epilepsy. Brain 2002;125:32-43.

30 Simantov R, Crispino M, Hoe W, Broutman G, Tocco G, Rothstein JD, Baudry M: Changes in expression of neuronal and glial glutamate transporters in rat hippocampus following kainate-induced seizure activity. Brain Res Mol Brain Res 1999;65:112-123.

31 Chan H, Zwingmann C, Pannunzio M, Butterworth RF: Effects of ammonia on high affinity glutamate uptake and glutamate transporter EAAT3 expression in cultured rat cerebellar granule cells. Neurochem Int 2003;43:137-146. 


\section{Cellular Physiology Cell Physiol Biochem 2016;40:1252-1260

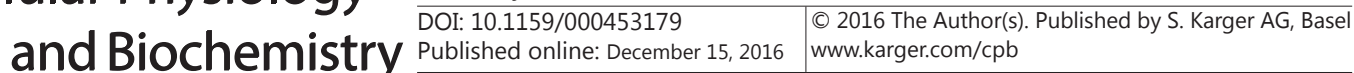 \\ Abousaab/Lang: GSK3B Up-Regulates EAAT3/4}

32 Kim MS, Shutov LP, Gnanasekaran A, Lin Z, Rysted JE, Ulrich JD, Usachev YM: Nerve growth factor (NGF) regulates activity of nuclear factor of activated T-cells (NFAT) in neurons via the phosphatidylinositol 3-kinase (PI3K)-Akt-glycogen synthase kinase 3beta (GSK3beta) pathway. J Biol Chem 2014;289:3134931360.

33 O'Brien WT, Klein PS: Validating GSK3 as an in vivo target of lithium action. Biochem Soc Trans 2009;37:1133-1138.

34 Valvezan AJ, Klein PS: GSK-3 and Wnt Signaling in Neurogenesis and Bipolar Disorder. Front Mol Neurosci 2012;5:1.

35 Fezai M, Warsi J, Lang F: Regulation of the $\mathrm{Na}+$,Cl- Coupled Creatine Transporter CreaT (SLC6A8) by the Janus Kinase JAK3. Neurosignals 2015;23:11-19.

36 Hosseinzadeh Z, Honisch S, Schmid E, Jilani K, Szteyn K, Bhavsar S, Singh Y, Palmada M, Umbach AT, Shumilina E, Lang F: The Role of Janus Kinase 3 in the Regulation of $\mathrm{Na}(+) / \mathrm{K}(+)$ ATPase under Energy Depletion. Cell Physiol Biochem 2015;36:727-740.

37 Almilaji A, Munoz C, Pakladok T, Alesutan I, Feger M, Foller M, Lang UE, Shumilina E, Lang F: Klotho sensitivity of the neuronal excitatory amino acid transporters EAAT3 and EAAT4. PLoS One 2013;8:e70988.

38 Fezai M, Ahmed M, Hosseinzadeh Z, Lang F: Up-Regulation of the Large-Conductance Ca2+-Activated K+ Channel by Glycogen Synthase Kinase GSK3beta. Cell Physiol Biochem 2016;39:1031-1039.

39 Mohamed MR, Alesutan I, Foller M, Sopjani M, Bress A, Baur M, Salama RH, Bakr MS, Mohamed MA, Blin N, Lang F, Pfister M: Functional analysis of a novel I71N mutation in the GJB2 gene among Southern Egyptians causing autosomal recessive hearing loss. Cell Physiol Biochem 2010;26:959-966.

40 Warsi J, Abousaab A, Fezai M, Elvira B, Lang F: Regulation of Voltage Gated K+ Channel KCNE1/KCNQ1 by the Janus Kinase JAK3. Cell Physiol Biochem 2015;37:2476-2485.

41 Warsi J, Abousaab A, Lang F: Up-Regulation of Excitatory Amino Acid Transporters EAAT1 and EAAT2 by ss-Klotho. Neurosignals 2015;23:59-70.

42 Warsi J, Fezai M, Fores M, Elvira B, Lang F: Up-Regulation of Voltage Gated K+ Channels Kv1.3 and Kv1.5 by Protein Kinase PKB/Akt. Cell Physiol Biochem 2015;37:2454-2463.

43 Elvira B, Warsi J, Fezai M, Munoz C, Lang F: SPAK and OSR1 Sensitive Cell Membrane Protein Abundance and Activity of KCNQ1/E1 K+ Channels. Cell Physiol Biochem 2015;37:2032-2042.

44 Fezai M, Elvira B, Warsi J, Ben-Attia M, Hosseinzadeh Z, Lang F: Up-Regulation of Intestinal Phosphate Transporter NaPi-IIb (SLC34A2) by the Kinases SPAK and OSR1. Kidney Blood Press Res 2015;40:555-564.

45 Warsi J, Singh Y, Elvira B, Hosseinzadeh Z, Lang F: Regulation of Large Conductance Voltage-and Ca2+Activated K+ Channels by the Janus Kinase JAK3. Cell Physiol Biochem 2015;37:297-305.

46 Ahmed M, Salker MS, Elvira B, Umbach AT, Fakhri H, Saeed AM, Shumilina E, Hosseinzadeh Z, Lang F: SPAK Sensitive Regulation of the Epithelial Na Channel ENaC. Kidney Blood Press Res 2015;40:335-343.

47 Elvira B, Munoz C, Borras J, Chen H, Warsi J, Ajay SS, Shumilina E, Lang F: SPAK and OSR1 dependent downregulation of murine renal outer medullary K channel ROMK1. Kidney Blood Press Res 2014;39:353-360.

48 Warsi J, Dong L, Elvira B, Salker MS, Shumilina E, Hosseinzadeh Z, Lang F: SPAK dependent regulation of peptide transporters PEPT1 and PEPT2. Kidney Blood Press Res 2014;39:388-398.

49 Alesutan I, Voelkl J, Stockigt F, Mia S, Feger M, Primessnig U, Sopjani M, Munoz C, Borst O, Gawaz M, Pieske B, Metzler B, Heinzel F, Schrickel JW, Lang F: AMP-activated protein kinase alpha1 regulates cardiac gap junction protein connexin 43 and electrical remodeling following pressure overload. Cell Physiol Biochem 2015;35:406-418.

50 Almilaji A, Honisch S, Liu G, Elvira B, Ajay SS, Hosseinzadeh Z, Ahmed M, Munoz C, Sopjani M, Lang F: Regulation of the voltage gated K channel Kv1.3 by recombinant human klotho protein. Kidney Blood Press Res 2014;39:609-622.

51 Warsi J, Hosseinzadeh Z, Elvira B, Bissinger R, Shumilina E, Lang F: Regulation of ClC-2 activity by SPAK and OSR1. Kidney Blood Press Res 2014;39:378-387.

52 Almilaji A, Sopjani M, Elvira B, Borras J, Dermaku-Sopjani M, Munoz C, Warsi J, Lang UE, Lang F: Upregulation of the creatine transporter Slc6A8 by Klotho. Kidney Blood Press Res 2014;39:516-525.

53 Fezai M, Elvira B, Borras J, Ben-Attia M, Hoseinzadeh Z, Lang F: Negative regulation of the creatine transporter SLC6A8 by SPAK and OSR1. Kidney Blood Press Res 2014;39:546-554.

54 Munoz C, Pakladok T, Almilaji A, Elvira B, Decher N, Shumilina E, Lang F: Up-regulation of Kir2.1 (KCNJ2) by the serum \& glucocorticoid inducible SGK3. Cell Physiol Biochem 2014;33:491-500. 


\section{Cellular Physiology Cell Physiol Biochem 2016;40:1252-1260 \begin{tabular}{l|l} 
DOI: 10.1159/000453179 & $\begin{array}{l}\text { O 2016 The Author(s). Published by S. Karger AG, Basel } \\
\text { www.karger.com/cpb }\end{array}$
\end{tabular} \\ Abousaab/Lang: GSK3B Up-Regulates EAAT3/4}

55 Fezai M, Ahmed M, Hosseinzadeh Z, Elvira B, Lang F: SPAK and OSR1 Sensitive Kir2.1 K+ Channels. Neurosignals 2015;23:20-33.

56 Warsi J, Elvira B, Bissinger R, Shumilina E, Hosseinzadeh Z, Lang F: Downregulation of peptide transporters PEPT1 and PEPT2 by oxidative stress responsive kinase OSR1. Kidney Blood Press Res 2014;39:591-599.

57 Rainesalo S, Keranen T, Saransaari P, Honkaniemi J: GABA and glutamate transporters are expressed in human platelets. Brain Res Mol Brain Res 2005;141:161-165.

58 Zoia C, Cogliati T, Tagliabue E, Cavaletti G, Sala G, Galimberti G, Rivolta I, Rossi V, Frattola L, Ferrarese C: Glutamate transporters in platelets: EAAT1 decrease in aging and in Alzheimer's disease. Neurobiol Aging 2004;25:149-157.

59 King N, Lin H, McGivan JD, Suleiman MS: Aspartate transporter expression and activity in hypertrophic rat heart and ischaemia-reperfusion injury. J Physiol 2004;556:849-858.

60 Gloy J, Reitinger S, Fischer KG, Schreiber R, Boucherot A, Kunzelmann K, Mundel P, Pavenstadt H: Amino acid transport in podocytes. Am J Physiol Renal Physiol 2000;278:F999-F1005.

61 Cooper TG, Wagenfeld A, Cornwall GA, Hsia N, Chu ST, Orgebin-Crist MC, Drevet J, Vernet P, Avram C, Nieschlag E, Yeung $\mathrm{CH}$ : Gene and protein expression in the epididymis of infertile c-ros receptor tyrosine kinase-deficient mice. Biol Reprod 2003;69:1750-1762.

62 Matthews JC, Beveridge MJ, Dialynas E, Bartke A, Kilberg MS, Novak DA: Placental anionic and cationic amino acid transporter expression in growth hormone overexpressing and null IGF-II or null IGF-I receptor mice. Placenta 1999;20:639-650.

63 Noorlander CW, de Graan PN, Nikkels PG, Schrama LH, Visser GH: Distribution of glutamate transporters in the human placenta. Placenta 2004;25:489-495.

64 O'Kane RL, Martinez-Lopez I, DeJoseph MR, Vina JR, Hawkins RA: Na(+)-dependent glutamate transporters (EAAT1, EAAT2, and EAAT3) of the blood-brain barrier. A mechanism for glutamate removal. J Biol Chem 1999;274:31891-31895. 